\title{
Effect of Accounting Information on Share Price of Quoted Banks in Nigeria
}

\author{
Meka Azuka Gloria, Nwadialor Eugene Okoye (PhD) \\ Department of Accountancy, Chukwuemeka Odumegwu Ojukwu University, \\ Uli, Anambra, Nigeria
}

\begin{abstract}
It is important for the investors to have a good understanding of the financial position of a company in other to make sound investment decisions. This study examined the relationship between accounting information and share price of quoted commercial banks in Nigeria for 10 years from 2007 to 2016. Expost facto research design was adopted and the data collected were analyzed using descriptive statistic, correlation and regression analysis. The study findings revealed that earnings per share and capital employed per share have positive and strong significant influence on share price of quoted banks in Nigeria. The study recommends the introduction of sector wise index which will help Investors to analyze the company's overall characteristics when making investment decisions, this is because the effects of accounting information on share price depends on both the firms and industry's overall characteristics.
\end{abstract}

KEY WORDS: Accounting Information, Earnings, Capital employed, Operating income and Share Price

\section{INTRODUCTION}

Accounting information is written information contained in a complete or partial financial report, such as statement of comprehensive income, financial position and cash flow of an organization; it can be in the form of periodic reports or special analyses. Accounting information is often a source of information for making decisions, such as pricing, production levels, product mix, outsourcing, inventory policy, customer servicing, labor negotiations, and capital investments Horngren (2005). Accounting information and its relation to decision making in general and particularly on share pricing of a developing country like Nigeria appear extremely important. For instance, it is important for the investors to have a good understanding of the financial position of an organization, in other to make sound investment decision based on the values of the firm and avoid those firms that their stock prices are boosted by irrational speculation. According to Kothari (2001) evaluation of companies is one of the principal demands in research about capital markets, after the findings of Ball and Brown in 1968, that changes in stock price correlate and associate with change in financial information, Basu (1997) found that bad news impact more on prices than good news and if we fail to consider this diverse effect, we may face lower coefficients of determination. Ang ,Goetzmann , Schaeferl (2011) also affirm that in an efficient market, the price of a security reflects all available information about its fundamental value.

Value is very important to the shareholders, investors and the management of the firms, they usually depend on accounting information for measuring these values, an increasing number of empirical studies indicate that, the financial statements of enterprises contain certain parameters that play a critical role in the course of their respective equities in the stock market and that change in accounting information ought to prompt change in the share price, if accounting information is helpful to illustrate price, how does these affect the share price? In this paper we study the effect of accounting information on the share price of quoted banks in Nigeria.

Numerous studies have investigated the connection between accounting information measures and share price. For example Asif, Arif, and Akbar (2016) a study conducted in Pakistan, examined the relationship between accounting information and share price. The resulting evidence suggested that 
accounting information parameters have significant influence on share price and they have joint explanatory power in determining stock prices while capital employed per share has negative influence on share price, Menaje (2012) in Philippine, studied the impact of accounting information on share price, the result shows a negative relationship between return on assets and share price and strong positive impact on share prices in the Philippines Stock Market, Bhatt and JK (2012) in Indian studied the impact of earnings per share on the market value of an equity share in the Indian context. The study concluded that earnings per share impacts the market value of an equity share in the Indian context, Agbaje, Busari and Adeboye(2014) in Nigeria, this study examined the extent to which accounting information management has enhanced the profitability of Nigerian banks. The finding revealed that accounting information had impacted significantly on the growth of profitability in Nigerian banks, Olugbenga and Atanda (2014) in Nigeria examined the relationship between accounting information and the Nigerian stock market behavior, The resulting evidence indicated that, accounting information has the capability to significantly influence stock price, Mgbame and Ikhatua (2013) in Nigeria examined if book value per share, dividend per share and earnings per share have significant effect on stock volatility in Nigeria. Findings revealed that there are enough evidences to reject the assumptions of conditional normality in stock prices data series and accept the existence of stock volatility in Nigerian stock market. Though previous studies have provided empirical evidence mostly on accounting information and share price, capital employed and operating income have been neglected in previous studies, most of the Nigerian studies were on accounting information and value relevance and none of them have studied the banking sector, the inclusion of these variables have great potential of providing deeper insight on the relationship between accounting information and share price. These are the gaps this study sought out to fill in knowledge.

\section{Objectives of the Study}

The main objective of this study is to examine the effect of accounting information on share price of quoted banks in Nigeria. The specific objectives include the following:

1. To determine the effect of earnings per share on the share price of quoted Nigerian banks.

2. To investigate the effect of Capital employed per share on the share price of quoted Nigerian banks.
3. To investigate the effect operating income per share on the share price of quoted Nigerian banks

\section{Research Questions}

This study seeks to provide answers to the following research questions:

1. How does earnings per share influences share price of quoted banks in Nigeria?

2. To what extent does capital employed per share influences the share price of quoted banks in Nigeria?

3. To what extent does capital employed per share influences the share price of quoted Nigerian banks

\section{Hypotheses}

The following null hypotheses have been specified for the purpose of this study:

Ho1 : Earnings per share has no significant effect on share price of quoted banks in Nigeria

Ho2 : Capital employed per share has no significant effect on share price of quoted banks in Nigeria

Ho3 : Operating income per share has no significant effect on share price of quoted banks in Nigeria

\section{REVIEW OF REATED LITERATURE}

Accounting information is one of the most significant sources of financial information for the investment analysts (Rodney, 2012), for example in company valuation, which is one of the most important application to which they are addressed. The primary objective of financial reporting is to provide information that would enrich the understanding of the users about the activities and performance of the organization. An entrepreneur uses accounting information to gauge the financial performance of his enterprise and provides the relevant information to keep the business financially sound. Accounting information is important for decision making, record keeping, discovery and prevention of theft, this information is also helpful when applying for a grant or loan, the availability of accounting information creates a good reputation of the organization investopedia(2017). Accounting information is very important to internal stock holders such as business owners, managers and employers.. Financial institutions use financial information to evaluate the ability to repay a loan. Potential investors use accounting information to asses funding needs for the organization. Lenders look at assets and liabilities to determine whether the business is a safe investment. 


\section{Share price:}

is the price of single share of a number of salable stocks of a company derivative or other financial assets investopedia (2017). In a lay mans term stock price is the highest amount someone is willing to pay for the stock or the lowest amount that it can be bought for. The value of any publicly listed firm can be derived from its share price. The managers usually depend on accounting information for measuring the value of firm and this information is also of interest for the potential investor to select appropriate stock Asif (2016). Share premium is the excess amount received by a firm over the par value of its share, share premium account is an equity account found on a company's balance sheet and it represents the additional amount the share holders paid over the par value of those shares.

\section{Earnings:}

Earnings per share are performance indicator ratio that is primarily of interest to existing and potential shareholders as well as their advisers (Okwuosa, 2005), they are the main determinant of share price because, earnings and the circumstances relating to them can indicate whether the business will be profitable or successful in the long run. Earnings per share represents the portion of a company's earnings net of tax, preferred stock and dividend that is allocated to each share of common stock, it can be calculated by dividing net income earned in a given reporting period usually quarterly or annually by the total number of shares outstanding during the same term (Investopedia, 2017). The revenue earned by a company after meeting cost of production, interest, depreciation and tax belongs to the equity share holders, it is a carefully scrutinized metric that is often used as a barometric to gauge company's profitability per unit of share outstanding (Bhatt, 2012). Earnings per share are the key drivers of share price; it can be calculated via two methods basically or fully diluted. Basic earnings per share is referred to the amount of earnings per ordinary share based on the number of shares outstanding during the reporting period while fully diluted earnings per share is the expansion of restricted number of shares in issue to include the effect of potential ordinary share currently existing, potential ordinary share will arise where at the end of accounting period a company has in issue some securities which do not at present have any right to equity earnings but may have so in future (Okwuosa, 2005). Earnings are made up of two components, a cash flow component also known as an objective part of earnings and accruals which is more inclined to subjective part of earnings and thus easily manipulated.

\section{Capital employed:}

is the total amount of capital used for the acquisition of profit; it is the value of all the assets employed in a business. The use of capital structure is considered as one of the mechanisms to mitigate the agency costs and thereby increase firm performance (Berger \&Bonaccorsi, 2006) as cited in Asif ( 2016). Capital employed is also known as fund employed, it is the total amount of capital used for the acquisition of profits. It is the value of all the assets employed in the business and can be calculated by adding fixed assets to working capital or subtracting current liabilities from total assets, capital employed represents the capital invested and can also be defined as equity plus loans which are subject to interest (Investopedia, 2016). Capital employed is made up of share holders funds and long term loan capital; it is equivalent in value to the company's net assets in its balance sheet (Davies, 2005).

\section{Operating income:}

is a synonym for earnings before interest and tax, it is also referred to as operating profit or recurring profit, operating income equals gross income less operating expenses, depreciation, amortization income, extraordinary income and expenses (Okwuosa, 2005). It gives a more accurate picture of a firm's profitability; it is the total amount of money that includes suppliers, labors, utilities and rent etc. If you are trying to decide what your budget should be, you need to know your companies full operating income. Operating income is an accounting figure that measures the amount of profit realized from a business operation, after deducting operating expenses such as cost of goods sold, wages and depreciation (Investopedia, 2013). It is the income resulting from a firm's primary business operations excluding extraordinary income and expenses; it is the different between operating revenue and operating expenses. The metrics that investors look at in a company's financial statement is the net operating income, generally it is used to calculate and analyze real estate investment, and it looks at the ability of its investments to generate income, net operating income can be calculated by subtracting a company's operating income from its gross operating expenses. The net operating income represents the productivity and cash flow of an investment. 


\section{Conceptual Model}

This study model was based on the accounting information ratios and share price of banks in Nigeria as suggested by the findings of Keong (2010), that further studies should be conducted using composite measures rather than focusing on equity, earnings and dividend as a separate measures, these were shown below.

Share price $=f$ (earnings per share, capital employed per share, and operating income per share).

\section{Efficient Capital Market Theory}

The theory of efficient capital market was first propounded in 1965 by Fama, in an efficient market, prices at all times fully reflect all available information that is relevant to their valuation, Ang Goetzmann, Schaeferl,(2011) also affirm to this definition. A market is said to be "efficient" if prices adjust quickly, without bias, to new information, as a result, the current prices of securities reflect all available information at any given point in time, so there will be no room for fooling investors.

\section{EMPIRICAL REVIEW}

\section{Earnings and Share Price:}

The effect of earnings on share price have been examined from several perspectives and different methods for example Asif, Arif, and Akbar (2016) a study conducted in Pakistan; examined the relationship between accounting information and share price for the period of 8 years, from 2006 to 2013 and OLS regression models were used to examine the relationships. The resulting evidence suggests that accounting information parameters have significant influence on share price and they have joint explanatory power in determining stock prices except capital employed which has negative influence on share price. However this work was carried out in a country other than Nigeria. Glezakos, Mylonakis, and Kafouros (2012) examined the impact of earnings and book value in the formation of stock prices on a sample of 38 companies listed in the Athens Stock Market during the 1996-2008 periods. The resulting evidence suggests that the joint explanatory power of the above parameters in the formation of stock prices increases over time. However this work was limited to only two explanatory variables. Bhatt and JK (2012) studied the impact of earnings per share on the market value of equity share in the Indian context; the study was based on data of 50 companies over a period of 5 years. The first 50 companies in the list of India's most valuable companies were selected, the study found that earnings per share has positive and strong significant influence on share price and concluded that earnings per share impacts the market value of an equity share in the Indian context, however other accounting information variables were not considered. Cheng, Liu and Schaeffer (1996) examined the effect of earnings performance on the information content of cash flows; the study revealed that both earnings and earnings change are value relevant. They argue that markets look to cash flow as alternative sources of information where earnings number proves insufficient, but was carried out side Nigeria. Raj (2011) examined the impact of earnings per share on stock prices of Malaysian banks, findings of the study concluded that there is a very stronge positive correlation between public bank's earnings per share and its stock price. Gjerde, Knivsfla and Saettem (2003) examined the value relevance of book value, earnings, cash flow and share price in the Korean stock market from 1994-2005 for the period of 10 years. The study found that book value was most value relevant of the three, followed by cash flow. They also show that value relevance of book values and cash flow are stronger than that of book values and earnings. Ijeoma (2015) examined the value relevance of accounting information in Nigeria, in order to ascertain whether certain accounting variables affects share prices on the Nigerian capital market, for the period of 13 years from 2001-2013, data of share price, book value per share, earnings per share and return on equity were sourced for. The study finding indicated a significant relationship between earnings, book value, returns on equity and share prices of the listed firms but the financial institutions were excluded. Okoye. ,Ifurueze and chukwuto,(2016) examined value relevance of accounting information in pre and post IFRS accounting period using earnings per share, and book value per share as the explanatory variables. The study findings revealed that earnings per share and book value per share were affected by the adoption of the IFRS. Oyerinde (2011) a study conducted in Nigeria on the relevance of accounting information in Nigerian stock market, selected 68 companies from the listed companies in the Nigerian stock market, the study avoided banks and other financial institutions, the findings reveals that there is a significant relationship between accounting information and the share price. 


\section{Operating Income and Share Price:}

have been examined by Bao (2004), who investigated value relevance of operating income versus nonoperating income in the Taiwan stock exchange. He performed three types of value relevance analysis return on equity analysis, price levels analysis and price change analysis, claiming that value can be defined by the return on equity, stock price level, or stock price change. The results of their study shows that the valuation models based on earning components have a higher explanatory power than those of earnings alone. The contribution of both operating income and non-operating income are not significantly dissimilar, that Investors should consider operating income as well as non- operating income when analyzing firm value in Taiwan stock exchange. Thus, operating income is value relevant when analyzing firm value. But not considering other variables as they jointly explained what happens to the share price. Christie and Chalevas (2010): investigated the effects of accounting ratio and stock return, the sample of 2,164 companies on Greece were selected for the period of 3 from 2004-2006. This study finding reveals that the significant growth in operating activities of a company positively affects stock returns. However this research concentrated on assessment of share value. Menaje (2012) this study examined the impact of selected financial variables on share price of publicly listed firms in Philippine and found a negative relationship between return on assets and share price and a strong positive impact between financial variables and share prices in the Philippines stock market.

The few studies carried out in Nigeria, with mix results were the works of (Olugbenga and Atanda(2014),Mgbame et al (2013), Agdaje et al(2014), Ijeoma(2015)and Oyerinde(2011 ), they mainly focused on accounting information and value relevance, accounting information in the pre and post IFRS periods, accounting information and other investment decisions other than the share pricing but to the best of the researchers knowledge the available literature on accounting information and share price in the banking industry with the variables (earnings per share, book value per share, capital employed per share, and operating income per share) is the work of
Asif et al (2016) which was carried out in Pakistan. No study has been done on the effect of accounting information on the share price of quoted commercial banks in Nigeria. This is the gap this study sorts out to fill in knowledge.

\section{METHDOLOGY}

In this study, ex post factor research design was adopted in the study due to the nature of data collected, the study used secondary sources of data (annual reports of the banks)

\section{Method of data analysis}

The data collected was analyzed using the multiple panel regression analysis because the study has a cross section of 12 banks for 10 years, these studies were limited to 12 banks for 10 years, making it 120 years / banking since we cannot manipulate data on those banks with incomplete records and the analytical tools used for the analysis were the descriptive statistics analysis, correlation and the regression analysis.

\section{Model specification}

The multiple regression model of share price versus indicators of accounting information was used to examine the relationship between the variables. The model of this relationship is presented below: Algebraic expression of the analytical model as in Asif (2016) is presented in equation $\mathrm{SP}=\mathrm{Bo}+\mathrm{B} 1$ $\mathrm{EPS}+\mathrm{B} 2 \mathrm{BVPS}+\mathrm{B} 3 \mathrm{CEPS}+\mathrm{B} 4 \mathrm{NOCPS}+\varepsilon$ then modified as

\section{SPit= Bo +B1 EPSit + B2 D B3 CEPSit + B4OIPSit+ cit ..................(1)}

Where $\mathrm{SP}=$ Share price is our dependent variable.

The Independent variables are EPS $=$ Earnings per share, CEPS=capital employed per share, OIPS=Operating income per share, eit $=A n$ error term of the model.

Where: $\beta 0$ is the constant of the model while $\beta 1, \beta 2$, $\beta 3$ are the coefficients of the independent variables.

$\mathrm{i}=$ Indexes individual banks, $\mathrm{t}=$ indexes share price in years $(\mathrm{t}=1,2,3,4,5,6,7,8,9,10)$ 
International Journal of Trend in Scientific Research and Development (IJTSRD) ISSN: 2456-6470

Table 1: Measurement and Description of Variables

Variables

Share price

Earnings per Share

Capital employed

per share

operating income

per share
Definition of variables

Share premium/number of outstanding shares, as given in the statement of financial position at the end of each financial year. Following the work of Asif (2016)

profit after tax /number of outstanding shares

as in the work of Raj(2011)

net assets /number of outstanding shares as in the work of Asif (2016)

operating income /number of outstanding shares as in the work of Bao (2004)

\section{Results}

Table 2: Descriptive Statistics Analysis table

\begin{tabular}{|c|c|c|c|c|}
\hline & SP & EPS & CEPS & OIPS \\
\hline Mean & 4.835583 & 4.006467 & 7.000875 & 0.593750 \\
\hline Median & 1.145000 & 0.312000 & 1.500000 & 0.360000 \\
\hline Maximum & 112.0000 & 101.0000 & 147.0000 & 6.250000 \\
\hline Minimum & 0.050000 & 0.030000 & 0.011000 & 0.020000 \\
\hline Std. Dev. & 13.11515 & 15.10919 & 20.47407 & 0.820668 \\
\hline Jarque-Bera & 10751.60 & 3338.305 & 4880.372 & 2399.665 \\
\hline Probability & 0.000000 & 0.000000 & 0.000000 & 0.000000 \\
\hline Observations & 120 & 120 & 120 & 120 \\
\hline
\end{tabular}

Where: $\mathrm{SP}=$ share price, $\mathrm{EPS}=$ Earnings per Share, $\mathrm{CEPS}=$ Capital employed per share, OIPS = Operating income per share,

No of cross sections $=12$, all data observation $1=120$, Note: $1 \%$ level of significances

This table show the mean, maximum, minimums values, standard deviation and jarqua bera which test for normality, It was observed that the average over 10 years period (2007-2016) quoted bank were all characterized by positive share price, as observed SP have a mean value of 4.835583 and a standard deviation of 13.11515. The maximum and minimum values stood at112.0000 and 0.050000 respectively the wide range between the maximum and the minimum values justifies the need for this study. The Jarque-Bera statistic value of 10751.60 and p-value of 0.00 confirms the normality of the data and suitability for generalization. It also indicates the absence of outliers in the data. The mean value for EPS stood at 4.006467 with a standard deviation of 15.10919 . The maximum and minimum values stood at 101.0000 and 0.030000 respectively. The Jarque-Bera statistic value of 3338.305 and p-value of 0.00 confirms the normality of the data and suitability for generalization. It also indicates the absence of outliers in the data. CEPS were observed to have a mean value of 7.000875 and a standard deviation 20.47407. The maximum and minimum values were 147.0000 and 0.011000 respectively, the Jarque-Bera statistic value of 4880.372 and $p$ value of 0.00 respectively while OIPS has a mean value of 0.593750 and the standard deviation stood at 0.820668 , the maximum and minimum values were 6.250000 and 0.020000 also the Jarque-Bera statistic value of 2399.665 and the $p$ value of 0.00 respectively Jarqua- bera which test for normality or the existence of outliers or extreme values among the variables show that all the variables are normally distributed at $1 \%$ level of significant this means that any variable with outlier are not likely to distort our conclusion and therefore reliable for drawing generalization. The large different between the maximum and the minimum values of these variables justify the need for this study.

\section{Correlation Analysis}

In examining the association among the variables, we employed the correlation matrix and the result is presented in the table 4.2 
International Journal of Trend in Scientific Research and Development (IJTSRD) ISSN: 2456-6470

Table 3: Correlation Matrix

\begin{tabular}{|c|c|c|c|c|}
\hline & SP & EPS & CEPS & OIPS \\
\hline SP & 1.000000 & 0.212207 & 0.682343 & 0.373049 \\
\hline EPS & 0.212207 & 1.000000 & 0.126707 & 0.072964 \\
\hline CEPS & 0.682343 & 0.126707 & 1.000000 & 0.478026 \\
\hline OIPS & 0.373049 & 0.072964 & 0.478026 & 1.000000 \\
\hline
\end{tabular}

Source: E view version 9

In examining the association among the variables we used the Correlation Matrix. This is used to check for multi co-linearity and to explore the association between the explanatory variables and the dependent variables. This result focused on the correlation between the share price SP and EPS earning per share, CEPS capital employed per share, OIPS operates income per share. The findings from the correlation matrix table show that there exist a positive association between share price and all the explanatory variables. However the associations were observed to be weakly associated with the EPS, and OIPS and strongly associated with the CEP, as their values are $.21, .68$, and .37 respectively.

\section{Regression Analysis}

However to examine the impact of the relationship between the dependent variables (share price) and the independent variables (EPS,CEPS and OIPS), we used multiple panel regression analysis since the data has both time series $(2007-2016)$ and cross sectional properties of (12 quoted commercial banks) and the result is presented below

\section{Table 4}

\begin{tabular}{|c|c|c|c|c|}
\hline $\begin{array}{c}\text { Variabl } \\
\mathbf{e}\end{array}$ & $\begin{array}{c}\text { Coefficie } \\
\text { nt }\end{array}$ & $\begin{array}{c}\text { Std. } \\
\text { Error }\end{array}$ & $\begin{array}{c}\text { t- } \\
\text { Statistic }\end{array}$ & Prob. \\
\hline EPS & 0.119878 & $\begin{array}{c}0.05769 \\
1\end{array}$ & $\begin{array}{c}2.07792 \\
3\end{array}$ & $\begin{array}{c}0.039 \\
9\end{array}$ \\
\hline CEPS & 0.407427 & $\begin{array}{c}0.04904 \\
8\end{array}$ & $\begin{array}{c}8.30668 \\
1\end{array}$ & $\begin{array}{c}0.000 \\
0\end{array}$ \\
\hline OIPS & 1.436774 & $\begin{array}{c}1.06041 \\
0\end{array}$ & $\begin{array}{c}1.35492 \\
3\end{array}$ & $\begin{array}{c}0.178 \\
1\end{array}$ \\
\hline
\end{tabular}

Source E-view version 9

R-squared $=0.48$, Adjusted R-squared $=0.47$, Note: $10 \%$ level of significance

\section{Discussion of findings}

In testing for the cause effect relationship between the dependent and the explanatory variables in the share price model, we observed that the R-square and adjusted R-square values were 0.48 which was the same result as in the work of Glezakos (2012) and 0.46 respectively this means that all our independent variables jointly explain $48 \%$ of what happens to the share price of quoted commercial banks in Nigeria over the ten year period (2007-2016)

In addition to the above, the specific findings from each explanatory variable were as follows: Earnings per share: based on the T stat value of 2.08 and the $\mathrm{P}$ value of 0.04 was found to have positive influence on our sampled quoted banks share price. However the influence was statistically significant since the $P$ value is less than $10 \%$. This result suggests that we should reject the null hypothesis which states that the EPS has no significant effect on share price of quoted Nigerian banks. This is in support of the work of Bhatt (2012) where earnings per share have positive strong influence on share price.

Capital employed per share based on the $\mathrm{T}$ stat of 8.31 and $\mathrm{P}$ value of 0.00 was found to have positive influence on quoted commercial banks share price however the influence was statistically significant since the $\mathrm{P}$ value is less than $10 \%$ this suggest that we should reject the null hypothesis which states that capital employed per share has no significant effect on share price of quoted banks in Nigeria and accept the alternate hypothesis, this is in contrary to the work of Asirf (2016) which found negative influence on capital employed per share.

Operating income per share based on the $\mathrm{T}$ stat of 1.35 and $\mathrm{P}$ value of 0.18 was found to have positive influence on share price of quoted commercial banks and the influence was not statistically significant since the $\mathrm{P}$ value is more than $10 \%$, this result suggest that we should accept the null hypothesis which state that operating income per share has no significant effect on share price of quoted banks in Nigeria and reject the alternate hypothesis, this is in contrary to the work of Bao (2004) which considered operating income as value relevant when analyzing firm value.

\section{Summary of Findings}

We studied the effect of accounting information on share price of quoted commercial banks in Nigeria and came up with the following findings:

1. All the explanatory variables jointly explain what happens to the share price offering additional support to the previously stated conclusion such as Glezakos at el (2012).

2. It was also found that earnings per share have positive influence on the share price and the Influence was statistically significant. 
3. Capital employed per share has strong positive and statistically significant effect on share price of quoted banks in Nigeria

4. Operating income per share has positive influence although not statistically Significant effect on share price of quoted banks in Nigeria

\section{Conclusions}

This study examined the effects of accounting information on share price of quoted Nigerian banks, in order to ascertain whether accounting information variables have the ability to influence share price. The scope of the study is limited to the data collected from quoted commercial banks in Nigeria from 2007 to 2016., the study findings reveals that accounting information with the selected variables (earnings per share, capital employed per share and operating income per share) jointly explain what happen to share price of the Nigerian banking industry, all the explanatory variables have positive influence on share price which indicates that accounting information variables have the capability to influence share price Olugbenga( 2014), also it was found that earnings per share and capital employed per share best explain what happen to share price of quoted commercial banks in Nigeria. This is in affirmation with the theory of efficient market which states that share price react fully to all information made available $\operatorname{Fama}(1999)$.

\section{Recommendations}

Based on the findings the study therefore recommends the following:

1. There is need for the introduction of sector wise index which will help Investors to analyze the company's overall characteristics when making investment decisions, since the effects of accounting information on share price depends on both the firms and industry's overall characteristics.

2. There is need for training on portfolio management in all sectors of the economy in other to enhance the quality of portfolio management since accounting parameter that is applicable in one sector may not be attainable in another sector.

3. Measures should be putting in place to check against dirty speculations in the Nigerian banking industry for example, training on efficient risk and portfolio management.

4. The evidence also indicated that accounting information particularly earnings per share and capital employed per share plays a significant role on share pricing in the Nigeria banking industry and should be considered while making investment decisions

\section{REFERENCES}

1. Agbaje, W. H., Busari, G. A.\&Adeboye, N. O.(2014)Effects of accounting information management on profitability of Nigerian banking industry, international Journal of humanities social sciences and education (IJHSSE) 1(2), September;100-105, available online at www.arcjournals.org.

2. Ang. A, Goetzmann. W. N. \& Schaeferl. S. M (2011) Review of the efficient market theory and evidence implication for active investment management.(Clarke efficient markets hypothesis)Journal of Financial Economics(June/Sept. 1978).

3. Asif, Arif, \& Akbar (2016), Impact of accounting information on share price: 3 (1) available online at $h t t p: / / d x . d o i . o r g / 10.5296 /$ ifb.v3i1.9323

4. Bao, B. H. \&Bao, D. H. (2004).Value relevance of operating income versus non-operating income in the Taiwan Stock exchange, advances in international accounting, 17(1): 103-117.

5. Basu, S (1997). The conservatism principle and the asymmetric timeliness of earnings. Journal of Accounting and Economics, 24(1), 3-37.

6. Bhatt \& JK (2012) Impact of Earnings per share on market value of an equity share: An Empirical study in Indian Capital market department of commerce, Bangalore University, Journal of Finance, Accounting and Management, 3(2), 1-14,

7. Chandrapala, P. (2013). The value relevance of earnings and book value: The importance of ownership concentration and firm size. Journal of competitiveness, 5(2), 98-107retrieved online at http://dx.doi.org/10.7441/joc.2013.02.07

8. Cheng A., Liu C. \& Schaeffer T (1996). Earnings permanence and the incremental information content of cash flows from operations. Journal of Accounting Research34: 173-181

9. Cooper, D., \& Schindler, P.(2008). Business research method (7th Ed). New York: McGrawHill.

10. Fama, E. F.( 1970). Efficient capital markets: A review of theory and empirical Work Journal of Finance 25, 383-41. 
11. Florou, C., \&Chalevas, C. (2010). Key accounting value drivers that affect stock returns evidence from Greece. Emerald, 36(11), 903-916.

12. Gjerde O., Knivsfla, K. H. \&Saettem F. (2003), "The Value relevance of financial reporting on the Bergen Stock Exchange," Institute for research in economics and business administration, Bergen.

13. Glezakos, M., Mylonakis, J., \&Kafouros, C. (2012).The Impact of accounting information on stock prices: Evidence from the Athens stock exchange. International Journal of Economics and Finance, 4(2) available online at. http://dx.doi.org/10.5539/ijef.v4n2p56

14. Hendriksen, E. S. \& Van-Breda, M. F. (1992).Accounting Theory, (5th Edition).Homewood, III: Irwin Publishers

15. Horngren CT, Bhimani A, Datar S \& Foster G (2005). Management and cost accounting Financial Times Prentice Hall Harlow.

16. Ijeoma. N. B (2015).Value relevance of accounting information on share prices. volume 3 , Issue 10 October, 2015 Pages: 328-34 available online at www.absronline.org/journals

17. Isimoya. D. C.(1986). Business finance. ( $2^{\text {nd }}$ ed), Management science publishing limited 105-7 Finbarr's collage road Akoka Lagos ISBN 9782404-07-1

18. Keong. W. J. (2010).Is there any effect of accounting information on stock price? Evidence from top 20 firms listed in FBM KLCI

19. Kothari. S. (2001).Capital markets research in accounting. Journal of Accounting and Economics, 105-231. Available online at http://dx.doi.org/10.1016/S01654101(01)00030-1

20. Lo.A (2007). What Happened to the Quants in August 2007, Journal of Investment management5, 5-54

21. Mathoko, J, Mathoko, F., \& Mathoko, P. (2007). Academic Proposal Writing. Nakuru, Kenya: Amu Press.

22. Menaje (2012) The impact of selected financial variables on share price of publicly listed Firms in Philippine, American international journal of contemporary .research 2 (9.)Available online at aijcrnet.com/ journals/..
23. Mgbame. C. O. \&Ikhatua. O. J.( 2013) Accounting information and stock volatility in the Nigeriancapital market: A Garch analysis approach. department of accounting, faculty of management sciences, university of Benin, BeninCity, international review of management and business research vol. 2 (1) available on line at www.irmbrjournal.com

24. Mondal, S.A \& Imran, M.S, (2010). Determinants of stock price: A case study on Dhaka stock exchange. International Journal of Finance, 2(3): 1-16.

25. Ohlson, J. A (1995).Earnings, book values and dividends in security valuation.contemporary accounting research, 11, 661688.availableatwww.absronline.org/journals

26. Okoye. E. I, Ifurueze M. S, \&chukwuto N.O,(2016) Value relevance of accounting information inpre and post IFRS period . Journal of accounting, business and social sciences, 1 (1) September; 118-130 available on line at www.accansuinforgmail.com

27. Okwuosa I. (2005) Advanced financial accounting manual. Published by Arnold consulting ltd. ISBN 978-8026-49-4 tel: 08023059725

28. Olugbenaga \& Atanda (2014) The relationship between financial accounting information and market values of quoted firms in Nigeria, Global Journal of contemporary research in accounting, auditing and business ethics (GJCRA) 1(1) 23113162) www.globalbizresearch.org

29. Osisioma, B. C (1999).Management information system. Enugu, J.B.H. Publications 255 P. Oyerinde (2011).Value relevance of accounting information in the Nigerian stock market, working paper convernant university Otta.

30. Prabath (2014).The impact of accounting variables on stock price, evidence from the Colombo stock exchange, sir Lanka, international journal of business and management 9,(5) retried on line at www.ccsenet.org/journal/index../34076

31. Raj (2011).The impact of earnings per share on stock price of listed banks in Malaysia, International journal of applied economics and finance 5(2): 114-126, available at http://ansinet.com 
International Journal of Trend in Scientific Research and Development (IJTSRD) ISSN: 2456-6470

32. Reilly, F. \& Brown, K. (2003): Investment analysis and portfolio management, U.S.A. Thomson South-Western.

33. Rodney, V. (2012).Accounting and accounting information. A Thesis Presented to the Department of Accountancy, University of Pretoria

34. Saeidi (2014) .The impact of accounting information system on the financial performance: A case study of TCS-India Journal of Fundamental and Applied Life Sciences4 (S4), 412-417. Available at www.cibtech.org/sp.ed/jls/ 2014/ 04/jls.htm
35. Soyode A (1982).Financial Accounting Principles and Practice (Graham Bums Inc.) U.K. Wang J., Fu, G., \&Luo, C (2013).Accounting information and stock price reaction of Listed companies empirical evidence from 60 Listed Companies in Shanghai Stock exchange., Journal of Business and Management, available at http://dx.doi.org/10.12735/jbm.v2i2p11

36. Wei, S. X. and Zhang C. (2006): The Chinese interbank stock market, an analysis of term Premiums, journal of Banking and Finance 31, 939-95

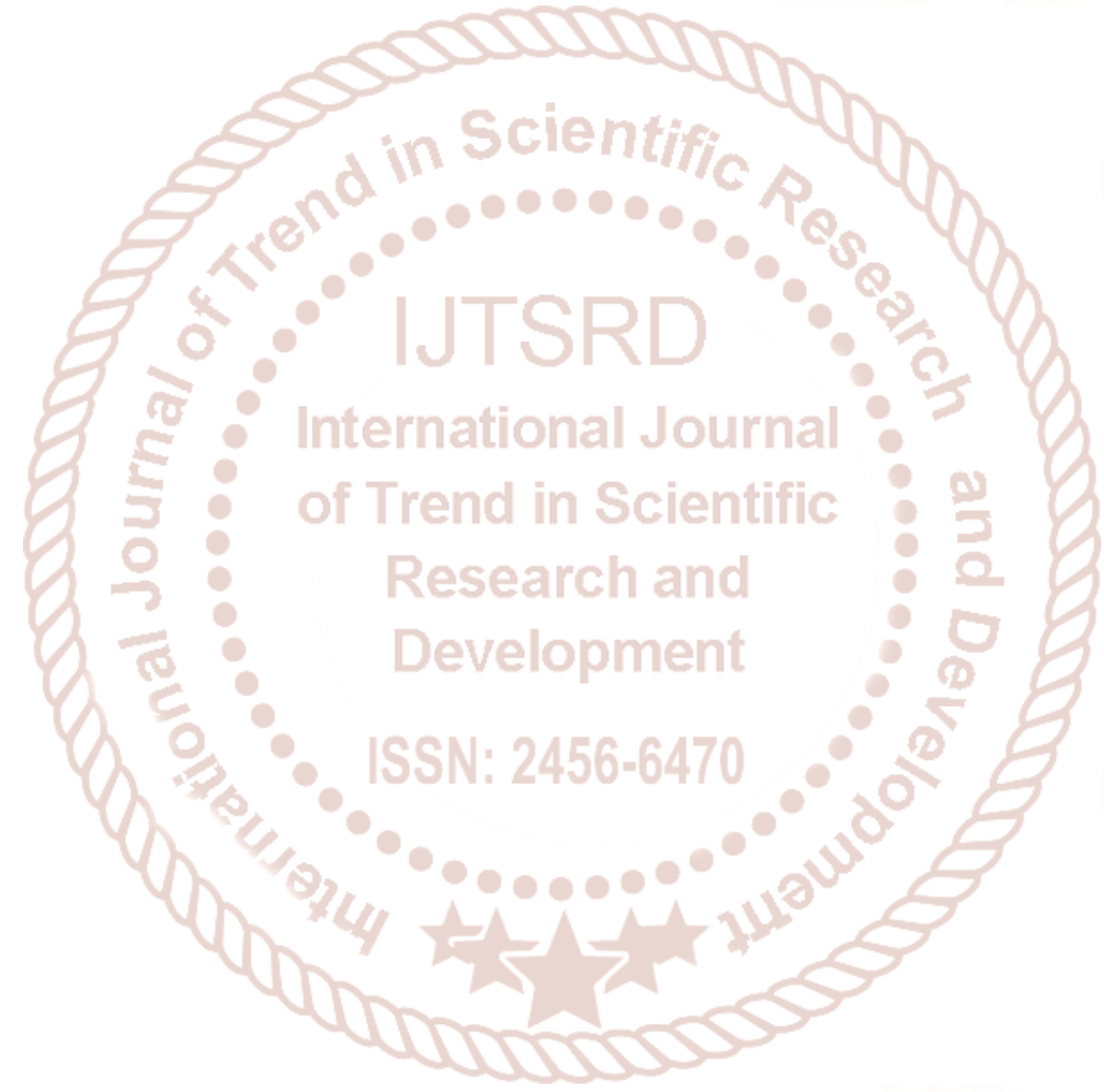

